\title{
The Major Floods in the Amazonas River and Tributaries (Western Amazon Basin) during the 1970-2012 Period: A Focus on the 2012 Flood*
}

\author{
JHAN CARLO ESPINOZA \\ Instituto Geofísico del Perú, and Universidad Agraria La Molina, Lima, Peru \\ JOSYANE RONCHAIL \\ Université Paris Diderot, Sorbonne Paris Cité, and Laboratoire d'Océanographie et de Climat: Expérimentation et \\ Approches Numériques, Paris, France \\ FRÉDÉRIC FRAPPART \\ Université de Toulouse, GET-OMP, and Groupe de Recherche en Géodésie Spatiale, Toulouse, France \\ WALDO LAVADO \\ Servicio Nacional de Meteorología e Hidrología, and Universidad Agraria La Molina, Lima, Peru \\ WILLIAM SANTINI AND JEAN LOUP GUYOT \\ Institut de Recherche pour le Développement, Lima, Peru, and Université de Toulouse, GET-OMP, Toulouse, France
}

(Manuscript received 27 June 2012, in final form 10 December 2012)

\begin{abstract}
In this work, the authors analyze the origin of the extreme floods in the Peruvian Amazonas River during the 1970-2012 period, focusing on the recent April 2012 flooding $\left(55400 \mathrm{~m}^{3} \mathrm{~s}^{-1}\right)$. Several hydrological variables, such as rainfall, terrestrial water storage, and discharge, point out that the unprecedented 2012 flood is mainly related to an early and abundant wet season over the north of the basin. Thus, the peak of the Marañon River, the northern contributor of the Amazonas, occurred sooner than usual (in April instead of May), coinciding with the peak of the Ucayali River, the southern contributor. This concomitance caused a dramatic flood downstream in the Peruvian Amazonas. These results are compared to the amplitude and timing of the three most severe extreme floods (1970-2011). The analysis of the climatic features related to the most important floods $(1986,1993,1999$, and 2012) suggests that they are characterized by a La Niña event, which originates a geopotential height wave train near the ground, with positive anomalies over the subtropical South and North Pacific and Atlantic and over southeastern South America. These patterns contribute to 1) the origin of an abundant humidity transport flux from the tropical North Atlantic and the Caribbean Sea toward the northwestern Amazon and 2) the maintenance of the monsoon flux over this region. They both favor a strong convergence of humidity in the northern Amazonas basin. Finally, the authors suggest that the intensity of floods is more likely related to an early La Niña event (as observed during the 2011/12 season), early rainfall, and simultaneous peaks of both tributaries of the Amazonas River.
\end{abstract}

\footnotetext{
* Supplemental information related to this paper is available at the Journals Online website: http://dx.doi.org/10.1175/ JHM-D-120100.s1.
}

Corresponding author address: Jhan Carlo Espinoza, Instituto Geofísico del Perú, Calle Badajoz 169, Urb. Mayorazgo IV Etapa, Ate Vitarte, Lima 03, Peru.

E-mail: jhan-carlo.espinoza@igp.gob.pe

\section{Introduction}

Inhabitants of the Peruvian Amazonian region have been recently suffering from the most extreme hydrological events since 1970, the beginning of the gauging measurements. Indeed, the driest episode was reported in austral winter and spring 2010 (e.g., Lewis et al. 2011; Marengo et al. 2011; Espinoza et al. 2011), while the 


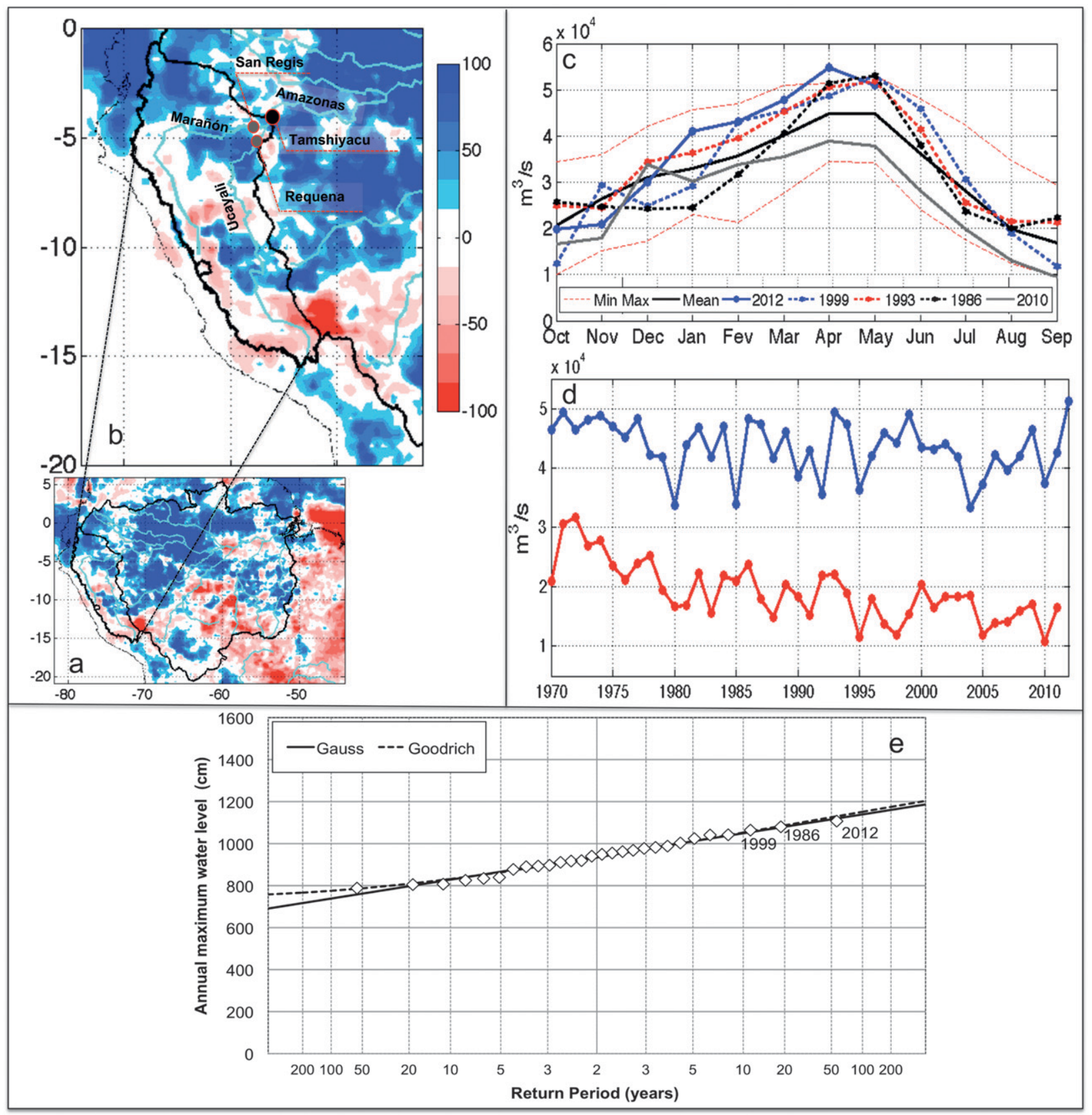

FIG. 1. JFM 2012 rainfall anomalies $\left(\mathrm{mm} \mathrm{day}^{-1}\right.$ ) from TRMM 3B42 v7 for (a) the Amazon basin and (b) the Peruvian Amazonas basin at Tamshiyacu. (c) Mean (1970-2011) hydrological year at Tamshiyacu station (black line). The red dashed lines represent the maximum and minimum discharge values. The highest discharges are indicated with a blue line (2011/12), a blue dashed line (1998/99), a red dashed line (1992/93), a black dashed line (1985/86), and a gray line (2009/10). (d) Mean March-May (blue) and August-October (red) discharge at Tamshiyacu station for the 1970-2012 period. (e) Return period of the annual maximum water level at Tamshiyacu station considering Gauss and Goodrich statistic distributions.

highest flooding was report in austral summer and autumn 2012. These recent events occur in a context of intensification of hydrological extremes since the end of the 1980s in the Amazon basin, which particularly affects the Andean rivers (Espinoza et al. 2009). Among them, the Amazonas River, the main western tributary of the Amazon, covers a $750000 \mathrm{~km}^{2}$ watershed at Tamshiyacu station (Figs. 1a,b). At this station, the longterm mean discharge is $32000 \mathrm{~m}^{3} \mathrm{~s}^{-1}$, which represents about $16 \%$ of the Amazon runoff (Espinoza et al. 2009). In the Amazonas River, severe droughts occurred in 1995, 1998, 2005, and 2010 austral winter and spring 
(Fig. 1d) (Espinoza et al. 2011). They have been frequently associated with a warmer-than-usual tropical North Atlantic in April-August (e.g., 1995, 2005, and 2010), the slowdown of the trade winds, and reduced water vapor transport toward the western Amazon (e.g., Marengo et al. 2008; Zeng et al. 2008; Cox et al. 2008; Tomasella et al. 2011; Marengo et al. 2011; Espinoza et al. 2011; Satyamurty et al. 2013; Lavado Casimiro et al. 2013). Some droughts, however, have been attributed to an El Niño event through a reduced water vapor transport in April-August caused by an anomalous divergence over the western Amazon (i.e., 1998). In 2010, both oceanic episodes caused the strongest drought observed in this region (Espinoza et al. 2011; Marengo et al. 2011).

Extreme high discharge values in the central and eastern parts of the Amazon basin have been documented in 1989, 1999, and 2009 (the highest values) austral summer and autumn (Chen et al. 2010; Marengo et al. 2012). They also occurred in the western Amazon in 1989 and 1999, but not in 2009 (Fig. 1d), suggesting that the hydroclimatic mechanisms responsible for flooding can differ between the downstream and the poorly documented upstream Amazon basin (Ronchail et al. 2006). Floods in the central Amazonian region are related to La Niña (i.e., 1989 and 1999) and to an anomalously southward migration of the intertropical convergence zone (ITCZ; i.e., 2009) (Marengo et al. 2012), but their origin is still not documented in western Amazon.

More recently, other types of extreme hydrological episodes have been observed, as an unprecedented discharge increase rate from September $2010\left(8300 \mathrm{~m}^{3} \mathrm{~s}^{-1}\right)$ to April $2011\left(49500 \mathrm{~m}^{3} \mathrm{~s}^{-1}\right)$, accompanied by a very strong increase in suspended sediment loads (Espinoza et al. 2012). The years characterized by an abrupt transition from drought to flooding in the Peruvian Amazonas have been related to a La Niña mode in the central equatorial Pacific during the austral summer and to the atmospheric teleconnections between the subtropical South Pacific and southeastern South America, which contributed to maintaining the monsoon flux (and humidity) over the western Amazon basin and to producing heavy rainfall and high water levels (Espinoza et al. 2012).

During the subsequent 2011/12 austral summer, intense rainfall was reported in a large part of the northern Amazonas basin (Figs. 1a,b), especially since November 2011 (see supplemental material files JHM-D-12-0100s1 and JHM-D-12-0100s2), which led to anomalously high discharge since January 2012 (Fig. 1c). This situation caused inundations in the main cities of the Peruvian Amazon region, affecting about 140000 people and leading the Peruvian authorities to declare a state of emergency (Decreto Supremo 037-2012-PCM). On 19 April the discharge at Tamshiyacu station attained
$55400 \mathrm{~m}^{3} \mathrm{~s}^{-1}$, which is the highest value reported in the Peruvian Amazonas River. As no work has been dedicated to the highest floods in the western Amazon basin, we aim, in this study, to document these events, including the latest 2012 one, and to analyze the still poorly known regional climatic features that originate hazards in this region.

\section{Hydroclimatic data}

In this study, we use mean monthly and daily river discharges data at Tamshiyacu, San Regis, and Requena stations, which are located on the Amazonas, Marañon, and Ucayali Rivers, respectively (Fig. 1b), the last ones being the main western and southern tributaries of the Amazonas River. The National Meteorology and Hydrology Service (SENAMHI of Peru) achieves the compilation and the control of daily water level data. The rating curves that allow the derivation of daily discharges from daily water level measurements are determined using acoustic Doppler current profiler (ADCP) gauging measures conducted by the Environmental Research Observatory (ORE) Geodynamical, Hydrological and Biogeochemical Control of Erosion/Alteration and Material Transport in the Amazon basin (HYBAM; www.ore-hybam.org). At Tamshiyacu, discharge values are available for the 1984-2012 period and extended to $1970-83$ using their correlation with the water level data measured at the nearby Iquitos hydrometric station (Espinoza et al. 2011, 2012). San Regis and Requena stations have shorter time series for the 1999-2012 and 1997-2012 periods, respectively. Rainfall anomalies for the 2011/12 austral summer are computed using rainfall estimations from the Tropical Rainfall Measuring Mission (TRMM) satellite provided by algorithm 3B42 v.7 (Huffman et al. 2007) with a $0.25^{\circ} \times 0.25^{\circ}$ spatial resolution. The period used for computing the climatology is 1998-2011. (This information is available at http://disc. sci.gsfc.nasa.gov/precipitation.)

The terrestrial water storage (TWS) in the Amazonas basin derived from the Gravity Recovery and Climate Experiment (GRACE) gravimetry from space mission. We use level 2 Groupe de Recherche de Geodesie Spatiale (GRGS) EIGEN-GL04 Release 2 (RL02) GRACE solutions from GRGS (Bruinsma et al. 2010) over the period August 2002 to January 2012, when the GRACE mission stops to provide data. They consist of 10-day (RL02) TWS grids, derived from normalized spherical harmonic coefficients from $2^{\circ}$ up to $50^{\circ}-60^{\circ}$ (corresponding to a spatial resolution of $400 \mathrm{~km}$ ) and resampled at $1^{\circ}$ spatial resolution. They are obtained without any smoothing or filtering using an empirical stabilization approach. (They are available at http://grgs.obs-mip.fr.) 
For more details about GRACE data descriptions and their applications in the Amazon basin, see Chen et al. (2010), Xavier et al. (2010), and Frappart et al. (2011a,b, 2012), among others.

To analyze the ocean variability, we use the global monthly sea surface temperature (SST) data available at $2^{\circ} \times 2^{\circ}$ resolution (Reynolds and Smith 1994) from the National Oceanic and Atmospheric Administration (NOAA)-Climate Prediction Center (CPC). To describe the atmosphere characteristics during the wettest episodes of the 1970-2012 period, we also examine the $2.5^{\circ} \times 2.5^{\circ}$ resolution horizontal and vertical winds, geopotential height, and specific humidity data from the National Centers for Environmental Prediction-National Center for Atmospheric Research (NCEP-NCAR) reanalysis (Kalnay et al. 1996). These data were obtained from the NOAA data server. The vertically integrated water vapor flux is derived from the specific humidity and the horizontal wind between the ground and $300 \mathrm{hPa}$ (Peixoto and Oort 1992).

\section{Hydrological characteristics of the extreme floods}

The discharge of the Amazonas River, which usually peaks in April-May (Fig. 1c), has been highly variable since the beginning of the 1980s, with very low high water observed in 1980, 1985, 1992, 1995, and 2004 and, on the contrary, high flows exceeding $50000 \mathrm{~m}^{3} \mathrm{~s}^{-1}$ in 1986, 1993, 1999, and 2012 (Fig. 1d). No significant trend appears in high flow series while low stage discharge values have been significantly $(p<0.01)$ diminishing from 1970 to 2011 (Fig. 1d).

Analyzing the annual cycle during extreme high flow years (Fig. 1c), different types of events are remarkable, in particular those with extreme values all along the rainy season and those with a sudden discharge increase rate during a short period. In 1986, for instance, which belongs to the second case, discharge was above average at Tamshiyacu station during two months, in April and May, after a rapid discharge increase since February. In May 1986, a discharge as high as $53080 \mathrm{~m}^{3} \mathrm{~s}^{-1}$ was attained that corresponded to a $+18.3 \%$ excess when compared with the average monthly maximum of the 1970-2012 period, and the 1986 daily peak was $53880 \mathrm{~m}^{3} \mathrm{~s}^{-1}(+17 \%$ when compared with the average 1970-2012 daily peak). In 1993, 1999, and 2012, which belong to the first category, discharge at Tamshiyacu station remained above the average during a much larger period. The flood lasted from February to June in 1999, with a monthly maximum discharge attaining $52190 \mathrm{~m}^{3} \mathrm{~s}^{-1}$ in May $(+16.4 \%)$ and a daily peak of $52960 \mathrm{~m}^{3} \mathrm{~s}^{-1}(+15 \%)$. In 1993 and 2012, high discharge values began still earlier, in austral summer, and remained high until June in 1993. In 1993, the highest monthly discharge occurred in May $\left(50910 \mathrm{~m}^{3} \mathrm{~s}^{-1},+13.5 \%\right)$, while the daily peak attained $51650 \mathrm{~m}^{3} \mathrm{~s}^{-1}(+12 \%)$. In 2012, the peak was observed in April, earlier than for the previous cases (Fig. 1c). It attained $54800 \mathrm{~m}^{3} \mathrm{~s}^{-1}$, the highest monthly discharge ever observed at Tamshiyacu station, that is, $22.3 \%$ above average April discharge (Fig. 1c). The daily peak reached $55420 \mathrm{~m}^{3} \mathrm{~s}^{-1}(+20 \%)$, the highest discharge ever measured at Tamshiyacu station.

Moreover, considering the wet period from January to May, the mean discharge in 2012 was $46900 \mathrm{~m}^{3} \mathrm{~s}^{-1}$ (+26\% when compared to the 1970-2012 average January-May discharge), while $41100 \mathrm{~m}^{3} \mathrm{~s}^{-1}$ (+10\%) in $1999,42400 \mathrm{~m}^{3} \mathrm{~s}^{-1}(+14 \%)$ in 1993 , and $36900 \mathrm{~m}^{3} \mathrm{~s}^{-1}$ $(-1 \%)$ in 1986 . These results demonstrate that the major flood observed in 2012 was also more persistent when compared to previous ones.

Finally, analyzing water level values at Tamshiyacu, which are directly observed, we can confirm that the 2012 flood was particularly strong (Fig. 1e). The maximum daily water level in 2012 at Tamshiyacu scale was $1107 \mathrm{~cm}$, while the second highest level (in 1986) reached $1080 \mathrm{~cm}$. Considering a Gaussian distribution, the return period corresponding to the 2012 water level is estimated to about 60 years, while it is only 19 years in the 1986 case (Fig. 1e). This result confirms the severity of the 2012 flood.

\section{Hydrological conditions of the 2012 flood in the Amazonas basin}

Positive rainfall anomalies were reported in the northwestern Amazonas basin since austral spring 2011, with an intensification in November (see supplemental file JHM-D-12-0100s2). They persisted from January to March 2012, especially in the northwestern Marañón basin (Fig. 1b). They caused an important increase of the TWS in December 2011 to January 2012 that reached a maximum in the Marañón basin over the GRACE observation period (Fig. 2c) but remained below its mean value in the Ucayali basin (Fig. 2d). Compared to 2009, the 2012 flood started one month earlier in the Marañón basin. In terms of spatial patterns, January 2012 positive TWS anomalies are spread over large regions in the northern Amazonas basin partly because of the coarse spatial resolution of GRACE data $(\sim 400 \mathrm{~km})$. In particular, over the lowlands near the city of Iquitos and over the Pacaya-Samiria Natural Reserve (at the confluence of Marañón and Ucayali), TWS anomalies reached up to $+100 \mathrm{~mm}$ of equivalent water height (EWH) in January 2012 (Fig. 2g), nearly 1 month after the beginning of heavy rains, while they were negative 


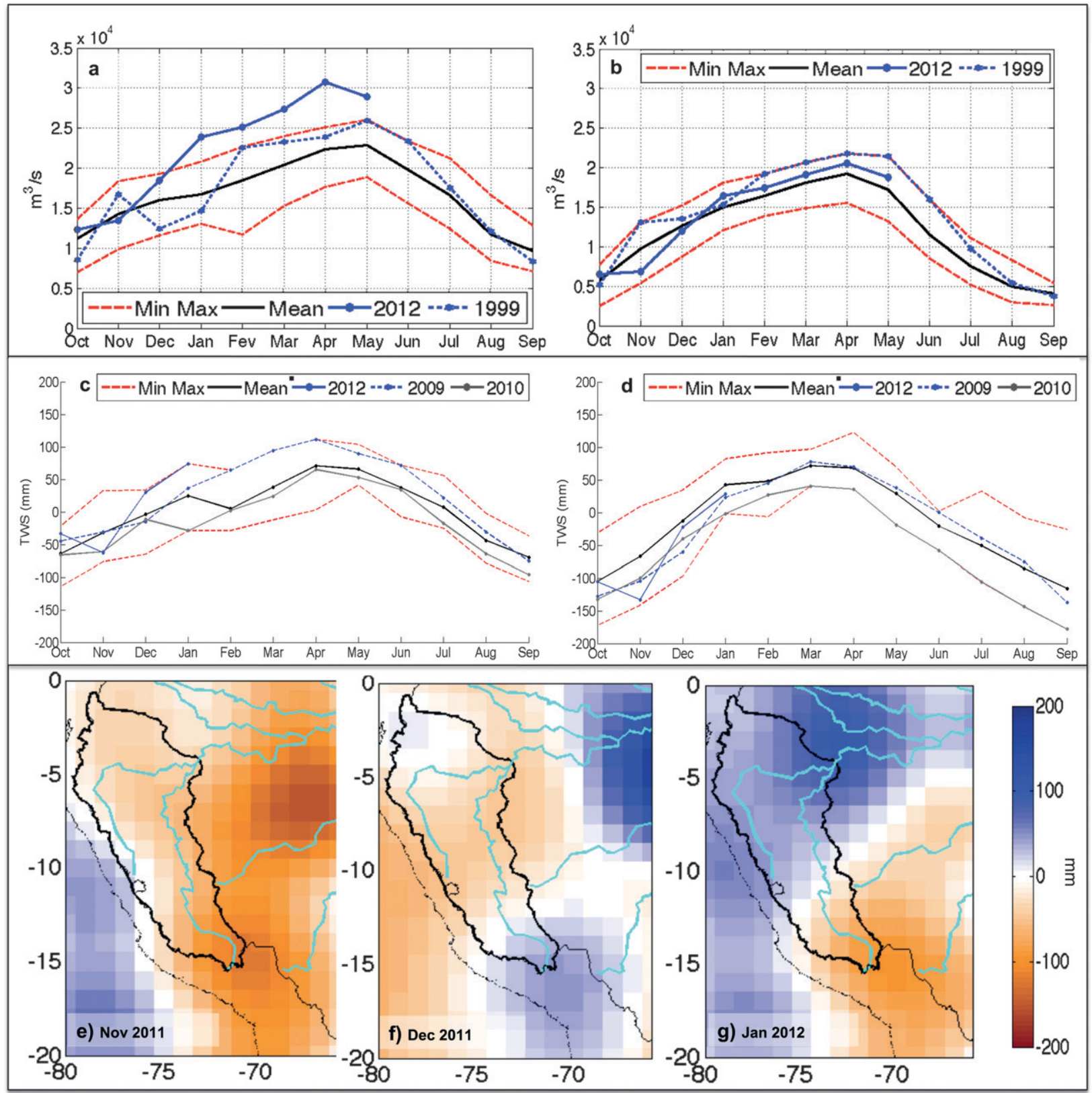

FIG. 2. (top) As in Fig. 1c, but for the (a) San Regis and (b) Requena stations. Data are not available for 1985/86 and 1992/93. (middle) Annual cycle of TWS from GRACE during the 2002-12 period for the (c) Marañón and (d) Ucayali basins, with mean hydrological year values represented by solid black line, minimum and maximum by dotted red lines, 2009 by dotted blue line, 2010 by solid gray line, and 2012 by solid blue line. (bottom) TWS anomalies from the monthly mean over the period February 2003 to January 2012 from GRACE GRGS RL02 solutions (EWH, mm) for (e) November 2011, (f) December 2011, and (g) January 2012.

in November (about $-50 \mathrm{~mm}$ ) and near the average in December (Figs. 2e,f) when compared to their 2002-12 monthly mean. In the southern part of the basin, TWS anomalies were negative in January, in particular over the upper Ucayali and Madre de Dios Rivers, reaching -50 to $-100 \mathrm{~mm}$ of EWH (Fig. $2 \mathrm{~g}$ ).

Consequently, since the middle of December 2011, the discharge of the Marañón River at San Regis station increased rapidly, attaining $23900 \mathrm{~m}^{3} \mathrm{~s}^{-1}$ in January $2012(+43 \%$ when compared to the mean January discharge), which is the highest discharge ever observed in this station in January. Thus, the Marañón peak occurred early, in April instead of May, reaching $30800 \mathrm{~m}^{3} \mathrm{~s}^{-1}$ ( $+37.5 \%$; Fig. 2a). On the contrary, in accordance with weaker rainfall anomalies over the Ucayali basin, the discharge peak at Requena stations 
did not reach historical values (Fig. 2b). An important fact, apart from the magnitude of discharge values, is that discharge peaks in both subbasins occurred simultaneously, in April, instead of being lagged as usual (Figs. 2a,b). This concomitance caused a dramatic flood in April, downstream of the confluence of both rivers. This phenomenon was not observed during the 1999 flood, the only other event for which discharge data are available in the subbasins. Indeed, in 1999, excess discharge occurred in both subbasins, and no modification was observed in their annual cycle (Figs. 2a,b). In 2012, at Tamshiyacu, discharge values were above average since January, and they peaked in April (Fig. 1c). In addition, the reduced water storage conditions at the beginning of the 2011/12 rainy season suggests that the magnitude of the 2012 flood is more likely related to the intense rainfall anomalies over the north of the basin than to the water storage from the previous rainy season.

\section{Climatic features during the extreme floods in the Amazonas River (1970-2012)}

In this section we analyze the oceanic and atmospheric conditions of the seasons that precede the Amazonas discharge peak, from October to December (OND; Fig. 3) and from January to March (JFM; see supplemental material file JHM-D-12-0100s3), and we discuss their role upon Amazonas floods. SST, geopotential height, and vertical integrated humidity flux anomalies (1970-2012) are averaged for the four strongest floods, with monthly discharge higher than $50000 \mathrm{~m}^{3} \mathrm{~s}^{-1}$ at Tamshiyacu $(1986,1993,1999$, and 2012; Figs. 3a-c), and are presented for the 2012 wettest episode (Figs. 3d-f). OND seasons are characterized by negative SST anomalies over the central equatorial Pacific, in particular over the $100^{\circ}-150^{\circ} \mathrm{W}$ region $\left(-1.5^{\circ} \mathrm{C}\right)$, featuring a La Niña event. Over the tropical Atlantic, no significant anomaly is observed (Fig. 3a). Similar features, but intensified, were predominant during OND 2011 in the central equatorial Pacific, where the SST anomalies attained $-2^{\circ} \mathrm{C}$ (Fig. 3d). Indeed, cold SST conditions in OND 2011 are comparable to 1998 anomaly (around $-1.5^{\circ} \mathrm{C}$ ), and they are cooler than during the other strong floods. These SST conditions favor positive 850-hPa geopotential height anomalies over the northern and southern Pacific (on the both sides of the cold SST anomalies, at about $40^{\circ} \mathrm{N}$ and $35^{\circ} \mathrm{S}$ ) and Atlantic (Figs. 3b,e). The succession of negative and positive 850-hPa geopotential height anomalies in the Northern and Southern Hemispheres, featuring an active Rossby train wave, is particularly clear and developed in OND 2011 (Fig. 3e). For instance, in the middle latitudes of the Southern Hemisphere, positive anomalies can be observed at $180^{\circ}$ and $50^{\circ} \mathrm{W}$, while negative anomalies are in between, at $125^{\circ} \mathrm{W}$ (Fig. 3b). Related enhanced geopotential height is observed over the midlatitude South American continent until the Chaco region. On the contrary, negative anomalies are observed over the South Atlantic convergence zone (SACZ) region. A specificity of the 2012 event is the development of a negative geopotential height anomaly over the western Amazon basin and northern South America during OND 2011 (Fig. 3e). The aforementioned SST and geopotential height anomalies suggest the establishment of the usual teleconnection patterns between the equatorial Pacific and southeast of South America (e.g., Vera et al. 2004) and between the equatorial Pacific and the North Atlantic (e.g., Hastenrath 2000), which was also observed during January-March 2011 (Espinoza et al. 2012). These geopotential patterns seem to favor the enhancement of convergence of humidity transport in western Amazon by means of two forcings.

\section{a. The northern Pacific-Atlantic wave train}

Directed by the positive geopotential height anomaly over the subtropical North Atlantic, the easterly humidity fluxes are intensified over the tropical and subtropical North Atlantic (Figs. 3c,f). They are deflected southward in the Caribbean Sea, increasing humidity fluxes toward northwestern South America and the Amazon. During OND 2011, the humidity advection flux toward the northwestern Amazon was stronger and consistent with the negative 850-hPa geopotential height anomalies developed over this region (Figs. 3e,f). In 2011, the northern humidity transport flux toward the northwestern Amazonas basin is the highest observed since 1970 (not shown).

\section{b. The southern Pacific-Atlantic wave train}

Southward, positive geopotential height anomalies (developed on the subtropical South Pacific and on southern South America) generate eastern water transport anomalies that deviate northward near the Andes, preventing the southward water transport (Figs. 3c,f) and featuring a reduced monsoon flux (including the low-level jet) toward the La Plata basin. This feature contributes to maintaining humidity over the western Amazon basin (Figs. 3c,f).

It seems that convergence is enhanced in the Amazon region as a consequence of both forcings. Indeed, during high flood years, a mean -2 standard deviations of divergence of humidity transport in northern Amazon (shading in Fig. 3c) is observed. This anomaly was stronger (about -4 standard deviations) in 2011/12 (shading in Fig. 3f), favoring exceptional rainfall (Figs. 1a,b) and 


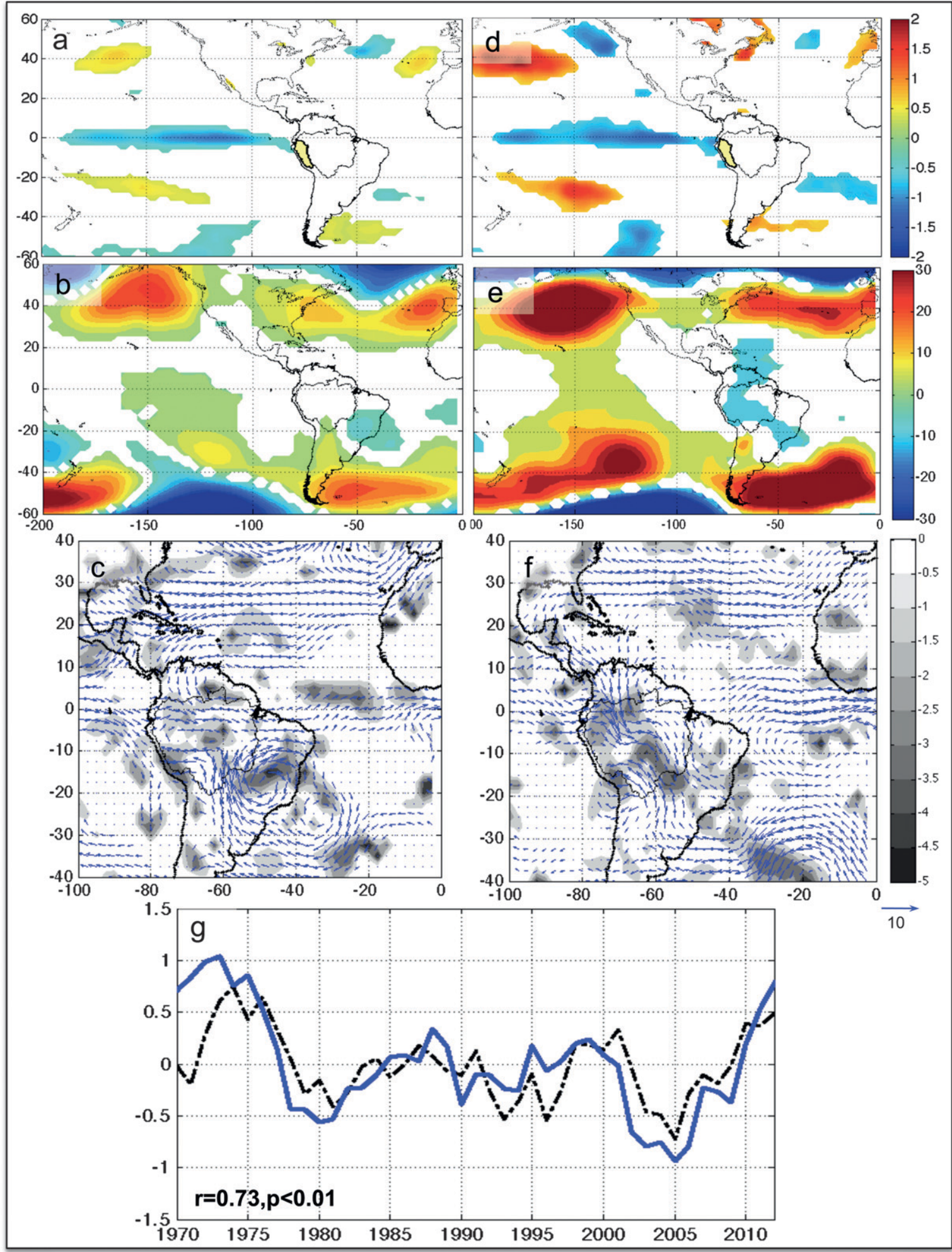

FIG. 3. Composite anomalies for OND 1985, 1992, 1998, and 2011 (a) SST ( $\left.{ }^{\circ} \mathrm{C}\right)$, (b) 850-hPa geopotential height (m), and (c) humidity transport flux $\left(\mathrm{kg} \mathrm{m}^{-1} \mathrm{day}^{-1}\right)$ and negative divergence standardized values (shading, without unit). (d)-(f) As in (a)-(c), respectively, but for 2011. Only values $>1$ std dev are plotted ( 2 std dev for SST data). (g) Standardized 4-yr running mean values of OND SST ( -1$)$ in the $4^{\circ} \mathrm{N}-4^{\circ} \mathrm{S}, 200^{\circ}-100^{\circ} \mathrm{W}$ region (black line) for the 1969-2011 period and March-April discharge at Tamshiyacu (blue line) for the 1970-2012 period. Running mean values at the beginning (end) of the time series are filled out with the first (last) values. 
discharge (Figs. 1c, 2a). In addition, this stronger convergence is consistent with the negative geopotential height anomalies observed over the western Amazon. The origin of this negative geopotential height merits future research.

SST anomalies during the JFM season for the composite years and for 2012 show the ending stage of a La Niña event, while the positive 850 -hPa geopotential height anomalies are still persistent over the northern subtropical Atlantic and on the Chaco region. Predictably, the southern humidity flux anomaly is still active and a high level of humidity convergence persists over the western Amazon (see supplemental material file JHM-D-12-0100s1). In 2012, the negative geopotential height anomalies observed in OND over the western Amazon persist in JFM.

The above-described increase of moisture transport from the north and the reduced southward transport during some wet episodes was recently reported in Satyamurty et al. (2013). Moreover, Espinoza et al. (2012) had already associated the rapid discharge increase with the La Niña event and its teleconnections. Here we propose that the earlier-than-usual onset of $\mathrm{La}$ Niña onset at the end of 2011 (in OND) and the related circulation features may contribute to the explanation of the premature peak in the Marañón River in April instead of May (Fig. 2a), its concomitance with the Ucayali peak, and the heavy flooding downstream in the Amazonas. Indeed, correlation between OND SST in the equatorial Pacific and the April-May discharge at Tamshiyacu station is high and significant $(r=-0.73, p<0.01)$, using 4-yr running mean values (Fig. $3 \mathrm{~g}$ ), while this correlation is weaker when JFM SST is used $(r=-0.62, p<0.01$; see supplemental material file JHM-D-12-0100s3). These results suggest that high discharges would be preferentially related to an early La Niña event in the central and western equatorial Pacific.

\section{Summary and concluding remarks}

The Amazonas River attained its highest discharge value $\left(55420 \mathrm{~m}^{3} \mathrm{~s}^{-1}\right)$ in April 2012, one month sooner than usual. During the 2011/12 austral spring and summer, intense and early rainfall affected the northwestern Amazon basin, especially the north of the Peruvian Amazon. They are confirmed by terrestrial water storage information that also shows positive anomalies over the north of the basin since January 2012, at the outbreak of the flood. Consequently, the northern Marañón tributary of the Amazonas River experienced early considerable discharge values ( $43 \%$ above the monthly average in January 2012), and the annual peak occurred sooner, in April instead of May, than the Ucayali River peak. Thus, this concomitance was an important additional fact to explain the intensity of the Amazonas flood $(+22.3 \%$ in April discharge) and its earliness (April instead of May).

Extreme flood years (1986, 1993, 1999, and 2012) are characterized by negative SST anomalies on the central equatorial Pacific during austral summer and spring. They generate geopotential wave trains with 1) positive $850-\mathrm{hPa}$ geopotential height anomalies over the northern subtropical Atlantic that enhance the easterly humidity fluxes over this region and northern fluxes from the Caribbean Sea toward the northwestern Amazon, particularly intense in 2011/12, and 2) geopotential height anomalies over the subtropical South Atlantic and South America that favor a southern humidity flux anomaly over the Amazon (i.e., a reduced monsoon flux). These features would contribute to explain the strong convergence of humidity flux observed over the northwestern Amazon, favoring rainfall and peak discharge. Finally, we show that the significant relationship between negative SST anomalies in the central equatorial Pacific and floods in the western Amazon is stronger when cold SST conditions are observed early (OND instead JFM), as reported during the 2012 flood.

\section{REFERENCES}

Bruinsma, S., and Coauthors, 2010: CNES/GRGS 10-day gravity field models (release 2) and their evaluation. Adv. Space Res., 45, 587-601, doi:10.1016/j.asr.2009.10.012.

Chen, J. L., C. R. Wilson, and D. B. Tapley, 2010: The 2009 exceptional Amazon flood and interannual terrestrial water storage change observed by GRACE. Water Resour. Res., 46, W12526, doi:10.1029/2010WR009383.

Cox, P. M., and Coauthors, 2008: Increasing risk of Amazonian drought due to decreasing aerosol pollution. Nature, 453, 212-215.

Espinoza, J. C., and Coauthors, 2009: Contrasting regional discharge evolutions in the Amazon basin (1974-2004). J. Hydrol., 375, 297-311.

_ , and Coauthors, 2011: Climate variability and extreme drought in the upper Solimões River (western Amazon basin): Understanding the exceptional 2010 drought. Geophys. Res. Lett., 38, L13406, doi:10.1029/2011GL047862.

— standing the abrupt 2010-11 hydrological annual cycle in the Amazonas River and tributaries. Environ. Res. Lett., 7, 024008, doi:10.1088/1748-9326/7/2/024008.

Frappart, F., and Coauthors, 2011a: Satellite-based estimates of groundwater storage variations in large drainage basins with extensive floodplains. Remote Sens. Environ., 115, 1588-1594, doi:10.1016/j.rse.2011.02.003.

, G. Ramillien, M. Leblanc, S. O. Tweed, M. P. Bonnet, and P. Maisongrande, 2011b: An independent component analysis approach for filtering continental hydrology in the GRACE gravity data. Remote Sens. Environ., 115, 187-204, doi:10.1016/ j.rse.2010.08.017.

, F. Papa, J. Santos da Silva, G. Ramillien, C. Prigent, F. Seyler, and S. Calmant, 2012: Surface freshwater storage and dynamics 
in the Amazon basin during the 2005 exceptional drought. Environ. Res. Lett., 7, 044010, doi:10.1088/1748-9326/7/4/044010.

Hastenrath, S., 2000: Upper air mechanisms of the Southern Oscillation in the tropical Atlantic sector. J. Geophys. Res., 105, 14 997-15009.

Huffman, G. J., and Coauthors, 2007: The TRMM Multisatellite Precipitation Analysis (TCMA): Quasi-global, multiyear, combined-sensor precipitation estimates at fine scales. J. Hydrometeor., 8, 38-55.

Kalnay, E., and Coauthors, 1996: The NCEP/NCAR 40-Year Reanalysis Project. Bull. Amer. Meteor. Soc., 77, 437-471.

Lavado Casimiro, W. S., D. Labat, J. Ronchail, J. C. Espinoza, and J. L. Guyot, 2013: Trends in rainfall and temperature in the Peruvian Amazon-Andes basin over the last 40 years (1965-2007). Hydrol. Processes, doi:10.1002/hyp.9418, in press.

Lewis, S. L., P. M. Brando, O. L. Phillips, G. M. F. van der Heijden, and D. Nepstad, 2011: The 2010 Amazon drought. Science, 311, 554, doi:10.1126/science. 1200807 .

Marengo, J. A., and Coauthors, 2008: The drought in Amazonia in 2005. J. Climate, 21, 495-516.

, J. Tomasella, L. M. Alves, W. R. Soares, and D. A. Rodriguez, 2011: The drought of 2010 in the context of historical droughts in the Amazon region. Geophys. Res. Lett., 38, L12703, doi:10.1029/2011GL047436.

, ——, W. R. Soares, L. M. Alves, and C. Nobre, 2012: Extreme climatic events in the Amazon basin. Theor. Appl. Climatol., 107, 73-85, doi:10.1007/s00704-011-0465-1.
Peixoto, J. P., and A. H. Oort, 1992: Physics of Climate. American Institute of Physics, $520 \mathrm{pp}$.

Reynolds, R. W., and T. M. Smith, 1994: Improved global sea surface temperature analyses using optimum interpolation. J. Climate, 7, 929-948.

Ronchail, J., and Coauthors, 2006: Impact of the Amazon tributaries on flooding in Obidos. IAHS Publ., 308, 220-225.

Satyamurty, P., C. P. Wanzeler da Costa, and A. O. Manzi, 2013: Moisture source for the Amazon Basin: A study of contrasting years. Theor. Appl. Climatol., 111, 195-209, doi:10.1007/ s00704-012-0637-7.

Tomasella, J., L. S. Borma, J. A. Marengo, D. A. Rodriguez, L. A. Cuartas, C. A. Nobre, and M. C. R. Prado, 2011: The droughts of 1996-1997 and 2004-2005 in Amazonia: Hydrological response in the river main-stem. Hydrol. Processes, 25, 1228 1242, doi:10.1002/hyp.7889.

Vera, C., G. Silvestri, V. Barros, and A. Carril, 2004: Differences in El Niño response over the Southern Hemisphere. J. Climate, 17, 1741-1753.

Xavier, L., M. Becker, A. Cazenave, L. Longuevergne, W. Llovel, and O. C. Rotunno Filho, 2010: Interannual variability in water storage over 2003-2008 in the Amazon basin from GRACE space gravimetry, in situ river level and precipitation data. Remote Sens. Environ., 114, 1629-1637, doi:10.1016/j.rse.2010.02.005.

Zeng, N., J.-H. Yoon, J. A. Marengo, A. Subramaniam, C. A. Nobre, A. Mariotti, and J. D. Neelin, 2008: Causes and impact of the 2005 Amazon drought. Environ. Res. Lett., 3, 014002, doi:10.1088/1748-9326/3/1/014002. 